\title{
PENGARUH LEVERAGE TERHADAP KEBIJAKAN DIVIDEN DENGAN FIRM SIZE DAN PROFITABILITAS SEBAGAI VARIABEL MEDIASI PADA PERUSAHAAN SEKTOR AGRIKULTUR DI BEI TAHUN 2014-2018
}

\author{
Mia Wahyu Nuraini \\ Universitas Negeri Surabaya \\ miawahyuwn@gmail.com
}

Abstract

\begin{abstract}
This research aims to know and analyze the influence of leverage on dividend policy with firm size and profitability as a mediating variable. This research was conducted on the agriculture sector listed on Indonesia Stock Exchange (IDX) period 2014-2018. The agriculture sector was chosen because his activities on IDX more fluctuate than another sector however, Product Domestic Bruto (PDB) rose consistently during 2014-2017. The type of this research is causal research with a quantitative approach. The population of this research is the agriculture sector listed on IDX period 2014-2018. The population in this research as many as 18 companies. This research sampled using a purposive sampling technique and retrieved nine companies as a sample. Methods of data analysis used in this research using Path Analysis with SmartPLS 3.0 analysis tools. This research found that leverage statistically significant positive to profitability, leverage does not affect the firm size and dividend policy, firm size statistically insignificant to dividend policy, profitability statistically insignificant to dividend policy. Both firm size and profitability can not be mediating variable between leverage and dividend policy. The result of this study hopefully can be used by companies agriculture sector to determine dividend policy. For investors, it is expected that it can be considered before investing.
\end{abstract}

Keywords: dividend policy; firm size; leverage; path analysis; profitability.

\section{PENDAHULUAN}

Investasi didefinisikan sebagai komitmen atas beberapa dana ataupun sumber daya lain yang dilakukan sekarang dan bertujuan mendapatkan beberapa manfaat di masa depan. Umumnya, investasi dibagi menjadi dua, yakni investasi pada aset real dan aset finansial (Tandelilin, 2010:2). Untuk melakukan investasi pada aset real, investor akan difasilitasi oleh pasar yang menyediakan jasa investasi aset finansial, yakni pasar finansial (financial market). Tandelilin (2010:30-31) membagi pasar fiansial menjadi dua jenis, yakni pasar uang (money market) dan pasar modal (capital market). Pasar modal pada dasarnya ialah pasar untuk sekuritas jangka panjang baik berupa utang ataupun ekuitas dan bermacam produk turunannya. Pasar modal memertemukan antara pihak yang mempunyai kelebihan dana dengan pihak yang memerlukan dana dengan memperdagangkan sekuritas (Tandelilin, 2010:26). Pasar modal menyediakan beragam produk sekuritas. Salah satu produk populer di kalangan masyarakat adalah saham. Saham adalah instrumen investasi yang sering dijadikan alternatif oleh para investor sebab saham dapat menghasilkan tingkat keuntungan yang menarik. Para investor memiliki tujuan utama guna meningkatkan kesejahteraannya yakni dengan harapan memeroleh keuntungan dengan membeli ataupun mempunyai saham (Nurhayati, 2013).

Investor berinvestasi dengan tujuan memeroleh pendapatan dalam bentuk dividen dan perbedaan antara harga jual dengan harga beli saham (capital gain). Investor sebagai pemegang saham mengharapkan keuntungan besar atau minimum dividen yang relatif stabil (Fitri et al., 2016). Investor yang melakukan investasi di pasar modal dihadapkan pada dua kondisi, yaitu risiko (risk) dan return. Sumber-sumber pengembalian investasi di pasar modal terbagi menjadi dua komponen utama, yakni capital gain (loss) serta yield. Yield ialah bagian dari pengembalian yang merefleksikan cash flow ataupun pemasukan yang didapatkan secara berkala dari investasi. Pada investasi saham, yield ditunjukkan dengan besaran dividen yang didapatkan investor (Tandelilin, 2010:102). Kebijakan dividen ialah keseluruhan kebijakan manajerial yang bertujuan untuk menentukan seberapa banyak keuntungan bersih yang berpotensi dibagikan sebagai dividen serta seberapa banyak keuntungan bersih yang ditahan untuk perusahaan. (Fitri et al., 2016). Dividen dapat dijelaskan sebagai kompensasi yang diberikan oleh suatu perusahaan kepada pemegang saham, baik pemegang saham 
preferen atau pemegang saham biasa dari laba yang dihasilkan dalam keuangan saat ini atau periode sebelumnya (Ogilo, 2016). Kebijakan dividen berkaitan dengan determinasi besaran dividen payout ratio, yakni besaran persentase laba bersih setelah pajak yang dibagikan sebagai dividen pada investor atau pemegang saham (Sudana, 2015:192).

Kebijakan dividen telah dianalisis selama beberapa dekade, namun tidak ada penjelasan yang diterima secara universal untuk perilaku dividen yang diamati pada perusahaan yang menjadi objek penelitian (Rafique, 2012). Menurut Khan \& Ahmad (2017), kebijakan dividen menjadi salah satu topik yang sering diperbincangkan dan selalu mendapat perhatian dari organisasi, analis keuangan, peneliti, investor, dan pemangku kepentingan lainnya. Kebijakan dividen merupakan salah satu dari sepuluh masalah utama keuangan perusahaan yang belum terpecahkan sehingga memerlukan lebih banyak penelitian untuk meningkatkan pemahaman kebijakan dividen. Grafik 1 menunjukkan pergerakan Dividend Payout Ratio pada 9 sektor perusahaan tahun 2014-2018.

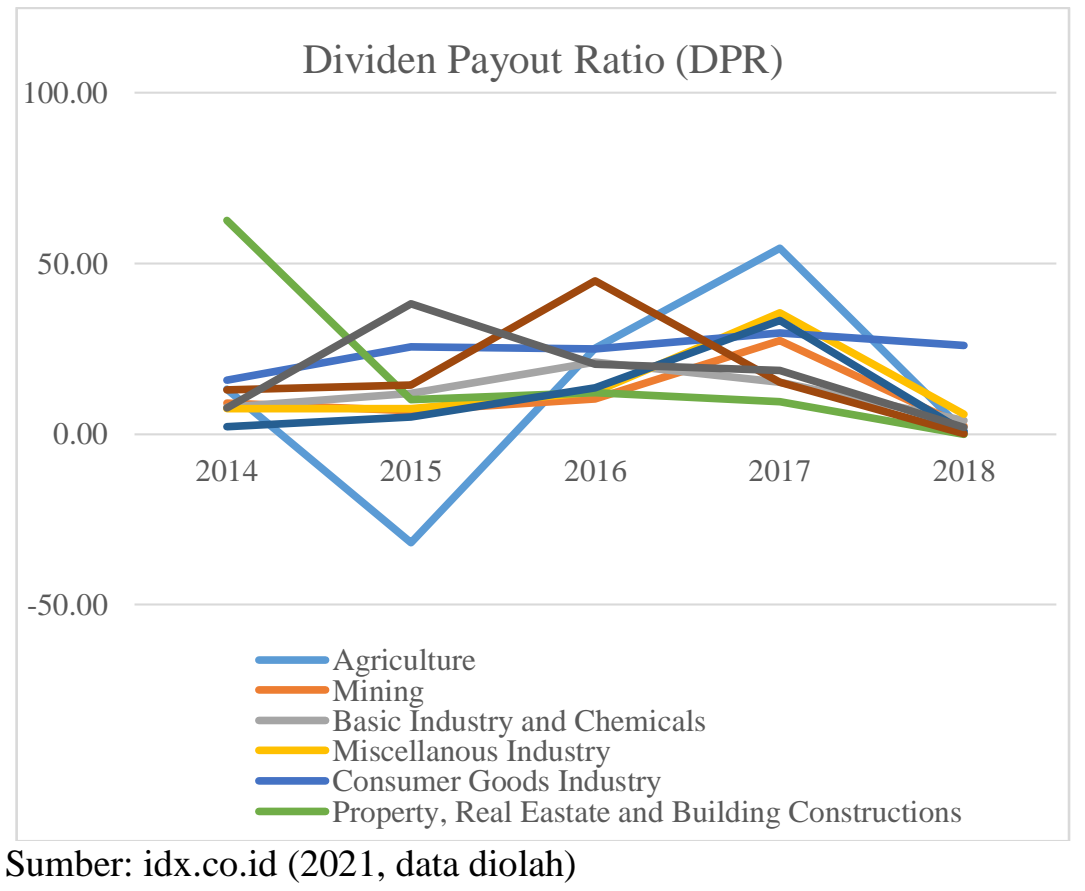

Gambar 1. GRAFIK FLUKTUASI DIVIDEND PAYOUT RATIO SEKTORAL 2014-2018

Gambar 1 menunjukkan pergerakan nilai rata-rata dividend payout ratio dari 9 sektor perusahaan yang bergerak secara fluktuatif dari tahun 2014-2018. Sektor agrikultur yang ditunjukkan dengan warna biru muda menunjukkan pergerakan yang sangat fluktuatif dibandingkan sektor yang lain. Tahun 2015, terjadi penurunan rata-rata dividend payout ratio hingga menyentuh angka minus dengan nilai rata-rata $-30,24 \%$ dikarenakan terdapat perusahaan yang tetap membayarkan dividen meskipun perusahaan mengalami kerugian pada perusahan ANJT dengan nilai DPR -96,9\% dan perusahaan SSMS dengan nilai DPR mencapai $-641,15 \%$. Kedua perusahaan tersebut mampu meraih keuntungan dan membagikan dividen tahun 2016 sehingga nilai DPR menunjukkan angka yang positif yaitu 97,67\% pada perusahaan ANJT dan 30,01\% pada perusahaan SSMS. Di sisi lain, terdapat perusahaan yang menunjukkan peningkatan nilai dividen yang signifikan yaitu pada perusahaan PALM dengan nilai DPR 136,41\% dan terus mengalami peningkatan di tahun 2017 menjadi 641,19\%. Sedangkan tahun 2018, hanya terdapat 1 perusahaan yang membayarkan dividennya, yaitu pada perusahaan AALI dengan nilai dividen $18,24 \%$. Hal ini menyebabkan nilai rata-rata DPR perusahaan sektor agrikultur bergerak sangat fluktuatif.

Berdasarkan data dari Badan Pusat Statistik (2018) Produk Domestik Bruto (PDB) atas dasar harga konstan 2010 sektor pertanian tahun 2014-2017 justru secara konsisten menunjukkan pergerakan positif yang meningkat dari tahun ke tahun. Tahun 2014 nilai PDB mencapai 1.129.052,7 miliar dan 
Mia Wahyu Nuraini. Pengaruh Leverage terhadap Kebijakan Dividen dengan Firm Size dan Profitabilitas sebagai Variabel Mediasi pada Perusahaan Sektor Agrikultur di BEI Tahun 2014-2018

terus meningkat pada angka 1.171.445,8 miliar di tahun 2015. Angka ini terus bergerak naik di tahun 2016 dengan nilai 1.210.749,8 miliar dan menyentuh nilai 1.256.894,3 miliar tahun 2017. Peningkatan ini terjadi karena pemerintah menjadikan sektor pertanian sebagai salah satu prioritas utama. Berbagai terobosan telah dilakukan oleh pemerintah, salah satunya memermudah alur ekspor yang tidak diharuskan melalui negara transit, namun bisa langsung ke negara tujuan sehingga pendapatan negara lebih tinggi. Langkah ini terbukti mampu mendongkrak nilai ekspor meningkat pesat dan berdampak pada peningkatan PDB sektor pertanian (Kementrian Pertanian Republik Indonesia, 2019). Berdasarkan hal tersebut, sektor agrikultur dipilih sebagai objek riset untuk mengkaji faktor-faktor yang memengaruhi pergerakan Dividend Payout Ratio melalui beberapa variabel penelitian yang akan diuji.

Variabel pertama yang memengaruhi kebijakan dividen adalah leverage. Leverage digunakan dengan tujuan mengukur kapabilitas perusahaan dalam membayarkan segala kewajibannya, baik jangka pendek ataupun jangka panjang jika dikemudian hari perusahaan dilikuidasi (Kasmir, 2017:151). Leverage muncul sebab perusahaan dalam operasinya memanfaatkan aset serta sumber dana yang memunculkan beban tetap untuk perusahaan (Sudana, 2015:180). Nurjanah \& Putri (2020) dan Perpatih (2016) mengemukakan bahwa leverage memiliki pengaruh signifikan positif terhadap DPR. Namun, Waswa et al., (2013) dan Nuhu (2014) menjelaskan bahwa leverage memiliki pengaruh signifikan negatif terhadap DPR. Temuan tersebut berbeda dengan Fitri et al., (2016) dan Wahyuni \& Hafiz (2018) yang mengemukakan bahwa leverage tidak berpengaruh signifikan.

Keunikan penelitian ini adalah melibatkan firm size sebagai variabel mediasi yang mengacu pada Meiliani \& Amboningtyas (2017). Penelitian tersebut menunjukkan variabel firm size mampu memediasi pengaruh leverage terhadap kebijakan dividen dengan hasil signifikan positif. Firm size menilai ukuran perusahaan yang didasarkan pada total penjualan bersih serta total aset. Semakin tinggi total aset ataupun penjualan, maka berbanding lurus dengan ukuran suatu perusahaan. Budiarso (2018) berpendapat semakin besar ukuran perusahaan berpotensi meningkatkan kemungkinan untuk membagikan dividen. Perusahaan besar dinilai mempunyai jalan masuk yang lebih mudah ke pasar modal guna mendapatkan dana dengan biaya yang lebih sedikit, sebaliknya perusahaan baru dan muda mendapati banyak kesulitan untuk mendapatkan akses menuju pasar modal. Hal tersebut membuat perusahaan besar cenderung membayarkan deviden lebih tinggi dibandingkan perusahaan kecil, sebab perusahaan yang lebih kecil cenderung menghasilkan laba yang lebih rendah. Menurut Tahir \& Mushtaq (2016) dan Gunawan \& Rusdianti (2019), firm size memiliki pengaruh positif dan signifikan terhadap DPR. Di sisi lain, Ofori (2018) mengemukakan terdapat pengaruh signifikan negatif antara firm size dan DPR. Temuan tersebut berbeda dengan Harun \& Jeandry (2018) dan Hanif \& Bustaman (2017) yang menjelaskan firm size tidak terbukti memiliki pengaruh yang signifikan terhadap DPR.

Keunikan riset berikutnya adalah melibatkan profitabilitas sebagai variabel mediasi yang mengacu pada Kautsar (2019). Variabel profitabilitas dipilih karena pada penelitian terdahulu, profitabilitas mempunyai banyak pengaruh yang sangat signifikan pada kebijakan dividen. Hasil riset tersebut menunjukkan bahwa profitabilitas mampu memediasi pengaruh leverage yang diukur melalui Debt to Equity Ratio (DER) pada kebijakan dividen dengan tingkat signifikasi signifikan positif. Profitabilitas berfungsi untuk menilai kapabilitas perusahaan dalam menghasilkan keuntungan (Kasmir, 2017:196). Profitabilitas mengukur kemampuan perusahaan untuk menghasilkan laba dan dianggap sebagai faktor penting yang dapat memengaruhi DPR. Hal ini disebabkan perusahaan yang menghasilkan lebih banyak laba dapat membayarkan dividen yang lebih besar untuk shareholder (Sumail, 2018). Purba et al. (20;19) dan Khan \& Ahmad (2017) menyatakan profitabilitas yang diukur menggunakan ROE berpengaruh signifikan positif terhadap DPR, sementara Banerjee (2018) menyatakan terdapat pengaruh signifikan negatif antara ROE dan DPR. Pada penelitian lain yang dilakukan oleh Mui \& Mustapha (2016) dan Rafique (2012) menunjukkan hasil yang berbeda, yakni ROE tidak terbukti memengaruhi DPR. 
Berdasarkan fenomena dan research gap yang ada, maka riset ini bertujuan untuk mengetahui dan menganalisis pengaruh leverage pada kebijakan dividen dengan profitabilitas dan firm size sebagai variabel mediasi pada perusahaan sektor agrikultur.

\section{KAJIAN PUSTAKA DAN PENGEMBANGAN HIPOTESIS}

\section{Teori Dividen Residual}

Teori dividen residual digunakan untuk menjelaskan variabel profitabilitas. Teori ini menyatakan bahwa dividen dibayarkan dari sisa laba yang tidak diperlukan untuk membiayai peluang investasi baru. Meski demikian, kebijakan pembayaran dividen residual memiliki daya tarik secara konseptual, yaitu dapat mengurangi biaya transaksi secara bersamaan kepada investor dan meningkatkan modal untuk membiayai investasi baru (Titman et al., 2014). Namun, hal ini dapat mengakibatkan aliran pembayaran dividen yang tidak stabil jika pendapatan dan peluang investasi perusahaan bervariasi dari tahun ke tahun. Akibatnya, terdapat konflik yang melekat antara keinginan untuk membayar sisa laba sebagai dividen dan memiliki kebijakan dividen yang stabil (Titman et al., 2014).

\section{Balancing Theory}

Balancing Theory menjelaskan semakin tinggi hutang perusahaan, sepanjang manfaatnya berbanding lurus maka memunculkan peluang untuk menambah hutang, sebab masih memberikan nilai tambah (profit). Teori tersebut menerangkan bahwa pendanaan yang diprioritaskan bersumber dari modal sendiri, hutang, dan modal eksternal (Kautsar, 2014). Lebih lanjut lagi, balancing theory mendukung variabel leverage pada penelitian ini.

\section{Firm Life Cycle Theory}

Life firm cycle theory menurut Mueller (1972) perusahaan di tahap awal pendiriannya mengalami ketidakpastian yang cukup besar, sehingga diperlukan banyak ide baru untuk mengatasi ketidakpastian tersebut. Pada tahap ini, pemegang saham menginginkan semua modal dan mungkin termasuk semua keuntungan diinvestasikan kembali untuk memunculkan ide baru dan memaksimalkan potensi keuntungan. Saat persaingan antar perusahaan berkembang dan perusahaan lain mulai mengadopsi dan menginovasi ide perusahaan, peluang keuntungan akan menurun akibat ketatnya tingkat persaingan. Proses ini dibarengi dengan terjadinya kejenuhan pasar. Selama periode ini, pemegang saham tidak ingin semua keuntungannya diinvestasikan kembali dan meminta manajer memaksimalkan kesejahteraan pemegang saham dengan membayarkan dividen (Mueller, 1972).

\section{Kebijakan Dividen}

Sudana (2015), menyatakan kebijakan dividen berkaitan dengan determinasi besaran Dividend Payout Ratio (DPR), yakni besaran presentase laba bersih setelah pajak yang dibagikan pada pemegang saham sebagai dividen. Menurut Sudana (2015), berikut adalah rumus dari dividend payout ratio (1).

$D P R=\frac{\text { Dividend Per Share }(D P S)}{\text { Earning Per Share }(E P S)}$

\section{Leverage}

Menurut Fahmi (2014:76), Rasio leverage mengukur seberapa besar biaya yang digunakan perusahaan menggunakan hutang. Fahmi (2014:76) merumuskan Debt to Equity Ratio (DER) sebagai berikut (2).

$D E R=\frac{\text { Total Liabilities }}{\text { Total Shareholders'Equity }}$

\section{Firm size}

Firm size (ukuran perusahaan) ialah ukuran yang menilai besar kecilnya perusahaan yang didasarkan pada banyaknya total aset, banyaknya penjualan, serta banyaknya karyawan suatu perusahaan (Kusumo \& Darmawan, 2016). Riset ini menggunakan logaritma normal dari total aset untuk mengukur besar atau kecilnya perusahaan. Menurut Kautsar (2014), logaritma normal digunakan 
Mia Wahyu Nuraini. Pengaruh Leverage terhadap Kebijakan Dividen dengan Firm Size dan Profitabilitas sebagai Variabel Mediasi pada Perusahaan Sektor Agrikultur di BEI Tahun 2014-2018

karena nominal total aset yang besar, sehingga logaritma natural digunakan untuk mengonversi angka total aset menjadi nominal yang lebih kecil serta menjadikan data total aset terdistribusi normal. Firm size dirumuskan dengan formula (3).

Firm Size $=$ Ln. Total Asset

\section{Profitabilitas}

Sudana (2015) menyatakan bahwa rasio profitabilitas difungsikan untuk menilai kapabilitas perusahaan dalam mendatangkan laba. Return On Equity (ROE) mengkaji seberapa jauh perusahaan memanfaatkan sumber daya yang dimiliki untuk menghasilkan keuntungan atas ekuitas. Fahmi (2014:83) merumuskan Return on Equity (ROE) sebagai berikut (4).

$R O E=\frac{\text { Earning After } T a x(E A T)}{\text { Shareholders' } E q u i t y}$.

\section{Hubungan antar Variabel}

Meiliani \& Amboningtyas (2017) mengungkapkan bahwa leverage memberikan pengaruh signifikan positif terhadap ukuran perusahaan (firm size). Perusahaan yang menambah utang untuk biaya operasional perusahaan akan membuat komposisi neraca pada sisi modal meningkat. Peningkatan ini berpengaruh kepada neraca pada sisi kiri atau aset ikut bertambah. Bertambahnya aset akan membuat ukuran perusahaan meningkat. Sehingga, semakin besar nilai Debt to Equity Ratio maka semakin besar juga ukuran perusahaan.

H1 : Leverage memiliki pengaruh terhadap firm size perusahaan sektor agrikultur yang terdaftar di Bursa Efek Indonesia tahun 2014-2018.

Menurut Kautsar (2019) dan Nadeem et al. (2015), Debt to Equity Ratio terbukti memberikan pengaruh signifikan positif pada profitabilitas, sehingga semakin banyak hutang perusahaan berpotensi meningkatkan kapabilitas perusahaan untuk menghasilkan laba. Hasil ini sesuai dengan balancing theory dan teori dividen residual, yaitu hutang perusahaan akan digunakan secara produktif untuk membiayai investasi dan proses operasional perusahaan. Jadi, peningkatan hutang akan menghasilkan kapabilitas operasional dan meningkatkan profitabilitas perusahaan.

$\mathrm{H} 2$ : Leverage memiliki pengaruh terhadap profitabilitas perusahaan sektor agrikultur yang terdaftar di Bursa Efek Indonesia tahun 2014-2018.

Perusahaan dengan leverage tinggi menghasilkan porsi yang lebih besar dari laba yang tersisa untuk pemegang ekuitas, sehingga menandakan bahwa semakin besar leverage semakin besar pula Dividend Payout Ratio (Banerjee, 2016). Hasil riset ini didukung oleh Nurjanah \& Putri (2020) yang menyatakan hubungan signifikan positif antara leverage dan kebijakan dividen. penelitian ini dijelaskan dengan balancing theory dan teori dividen residual. Peningkatan hutang perusahaan akan dioptimalkan untuk kegiatan operasional sehingga produksi meningkat. Peningkatan produksi akan berdampak pada meningkatnya penjualan sehingga profitabilitas meningkat. Peningkatan inilah yang membuat kapabilitas perusahaan untuk membagikan dividen semakin tinggi.

H3 : Leverage memiliki pengaruh terhadap kebijakan dividen perusahaan sektor agrikultur yang terdaftar di Bursa Efek Indonesia tahun 2014-2018.

Menurut Meiliani \& Amboningtyas (2017), ada pengaruh positif dan signifikan antara firm size dan Dividend Payout Ratio. Riset ini didukung oleh Mui \& Mustapha (2016) yang menunjukkan pengaruh signifikan positif firm size terhadap DPR. Berdasarkan firm life cycle theory, perusahaan yang lebih besar memiliki kecenderungan untuk membayarkan dividen lebih besar sebab perusahaan yang lebih besar cenderung lebih dewasa dan mempunyai arus kas yang lebih tinggi.

H4: Firm size memiliki pengaruh terhadap kebijakan dividen perusahaan sektor agrikultur yang terdaftar di Bursa Efek Indonesia tahun 2014-2018. 
Menurut Purba et al. (2019) dan Meiliani \& Amboningtyas (2017), ada pengaruh signifikan positif profitabilitas yang diproksikan dengan ROE pada Dividend Payout Ratio. Hasil tersebut dikarenakan perusahaan besar yang telah menghasilkan laba yang tinggi serta profitabilitas yang konstan mempunyai jalan masuk yang lebih mudah menuju pasar modal ataupun mendapatkan sumber pendanaan dari luar untuk pembiayaan. Oleh sebab itu perusahaan dewasa berpeluang memiliki tingkat dividen yang lebih besar dibanding dengan perusahaan kecil ataupun masih baru (Purba et al., 2019). Mengacu dari teori dividen residual, semakin besar profit yang diperoleh perusahaan maka berbanding lurus dengan dividen yang akan dibagikan (Kautsar, 2014).

H5 : Profitabilitas memiliki pengaruh terhadap kebijakan dividen perusahaan sektor agrikultur yang terdaftar di Bursa Efek Indonesia tahun 2014-2018.

Menurut Meiliani \& Amboningtyas (2017), variabel firm size mampu memediasi pengaruh leverage yang diproksikan dengan DER terhadap Dividend Payout Ratio dengan tingkat signifikasi segnifikan positif. Hasil temuan tersebut berhasil membuktikan dugaan mengenai adanya pengaruh firm size yang memediasi hubungan leverage dan Dividend Payout Ratio.

H6 : Firm size mampu memediasi hubungan leverage terhadap kebijakan dividen perusahaan sektor agrikultur yang terdaftar di Bursa Efek Indonesia tahun 2014-2018.

Kautsar (2019) mengemukakan variabel profitabilitas yang diproksikan dengan Return on Equity (ROE) terbukti mampu memediasi pengaruh leverage terhadap Dividend Payout Ratio dengan tingkat signifikasi signifikan positif. Hal ini berarti peningkatan hutang yang diikuti oleh meningkatnya profitabilitas akan meningkatkan potensi pembayaran dividen terhadap pemegang saham.

H7 : Profitabilitas mampu memediasi hubungan leverage terhadap kebijakan dividen perusahaan sektor agrikultur yang terdaftar di Bursa Efek Indonesia tahun 2014-2018.

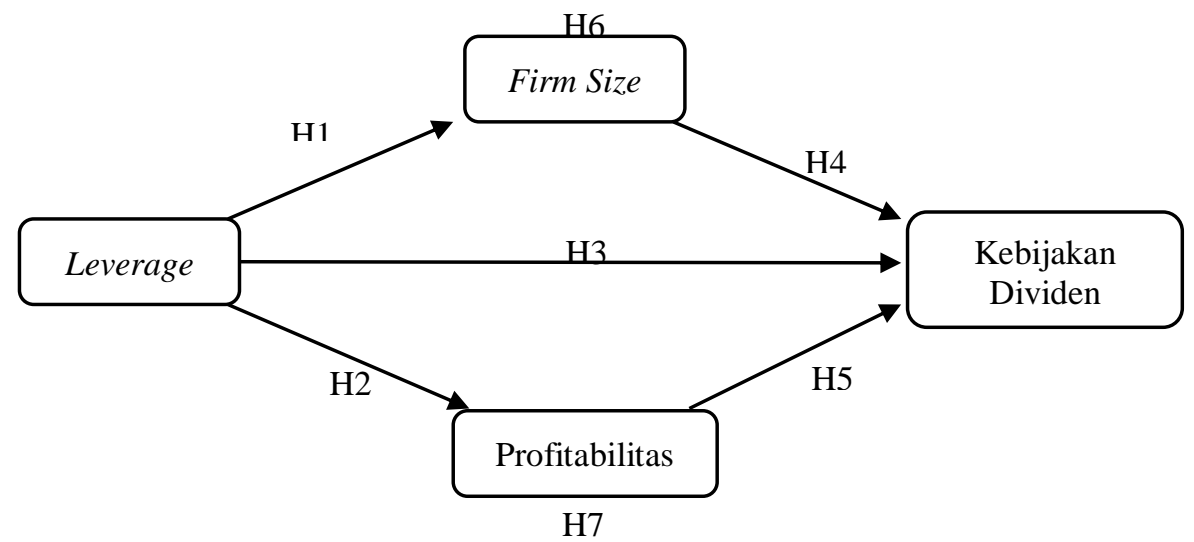

Gambar 2. KERANGKA KONSEPTUAL

\section{METODE PENELITIAN}

Riset ini menggunakan pendekatan kuantitatif dan jenis penelitian sebab akibat (causal), yakni pengaruh leverage pada kebijakan dividen dengan variabel firm size dan profitabilitas sebagai variabel mediasi. Data yang dipakai adalah data sekunder yang didapatkan dari literatur, buku, referensi, serta informasi laporan keuangan tahunan perusahaan go public dari sektor agrikultur yang terdaftar di Bursa Efek Indonesia dan didapatkan dari situs resmi Indonesia Stock Exchange (IDX) www.idx.co.id serta website resmi dari masing-masing sampel perusahaan.

Populasi yaitu perusahaan sektor agrikultur yang terdaftar di Bursa Efek Indonesia (BEI) tahun 20142018 dan ditetapkan sampel 9 perusahaan. Metode yang digunakan untuk pengumpulan sampel ialah teknik purposive sampling dengan kriteria: perusahaan yang terdaftar di Bursa Efek Indonesia (BEI) tahun 2014-2018; perusahaan mengunggah laporan keuangan sepanjang tahun 2014-2018; dan 
Mia Wahyu Nuraini. Pengaruh Leverage terhadap Kebijakan Dividen dengan Firm Size dan Profitabilitas sebagai Variabel Mediasi pada Perusahaan Sektor Agrikultur di BEI Tahun 2014-2018

perusahaan membayarkan dividen minimal tiga kali selama periode pengamatan. Teknik analisis menggunakan path analysis dengan SmartPLS 3.0. Data yang telah ditabulasi akan dilakukan uji Outer Model dan uji Inner Model.

\section{HASIL DAN PEMBAHASAN}

\section{Hasil Uji Outer Model}

\section{Tabel 1. OUTER WEIGHT}

\begin{tabular}{lc}
\hline \multicolumn{1}{c}{ Variabel } & Outer Weight \\
\hline DER $\leftarrow$ Leverage & 1.000 \\
Ln. TA $\leftarrow$ Firm size & 1.000 \\
ROE $\leftarrow$ Profitabilitas & 1.000 \\
DPR $\leftarrow$ Kebijakan Dividen & 1.000 \\
Sumber: SmartPLS 3.0 (2021, data diolah)
\end{tabular}

Tabel 1 menunjukkan nilai outer weight yang dihasilkan seluruh konstruk formatif bernilai 1,000 atau lebih dari 0,05 . Hasil tersebut menjelaskan bahwa setiap variabel valid atau memenuhi uji validitas.

\section{Hasil Uji Inner Model}

Tabel 2.

R SQUARE

\begin{tabular}{lc}
\hline \multicolumn{1}{c}{ Variabel } & R-Square \\
\hline Firm size & 0,043 \\
Profitabilitas & 0,080 \\
Kebijakan Dividen & 0,066 \\
\hline Sumber: SmartPLS 3.0 (2021, data diolah)
\end{tabular}

Tabel 2, nilai $R$-Square firm size 0,043. Artinya variabel firm size dipengaruhi leverage sebesar 4,3\% dan $95,7 \%$ dipengaruhi variabel lain. Nilai R-Square profitabilitas 0,080. Variabel profitabilitas dipengaruhi leverage sebesar $8 \%$ sedangkan $92 \%$ dipengaruhi variabel lain.Kebijakan dividen memiliki nilai $R$-Square 0,066. Artinya variabel kebijakan dividen leverage melalui variabel firm size dan profitabilitas sebesar 6,6\% dan 93,4\% dijelaskan oleh variabel lain. Keseluruhan model tersebut tergolong dalam kategori lemah karena memiliki nilai kecil, yaitu 4,3\%, $8 \%$ dan 6,6\%.

\section{Hasil Uji Measurement Bootstraping}

Tabel 3.

PATH COEFFICIENTS DAN INDIRECT EFFECTS

\begin{tabular}{lcccl}
\hline \multicolumn{1}{c}{ Variabel } & $\begin{array}{c}\text { Original } \\
\text { Sampel }\end{array}$ & T-statisticss & P-values & \multicolumn{1}{c}{ Keterangan } \\
\hline $\mathrm{DER} \rightarrow$ Ln. TA & 0,207 & 1,795 & 0,073 & Positif/Tidak Signifikan \\
$\mathrm{DER} \rightarrow$ ROE & 0,283 & 2,069 & 0,039 & Positif/Signifikan \\
$\mathrm{DER} \rightarrow$ DPR & $-0,023$ & 0,156 & 0,876 & Negatif/Tidak Signifikan \\
Ln. TA $\rightarrow$ DPR & 0,104 & 0,669 & 0504 & Positif/Tidak Signifikan \\
$\mathrm{ROE} \rightarrow$ DPR & 0,282 & 1,078 & 0,281 & Positif/Tidak Signifikan \\
$\mathrm{DER} \rightarrow$ Ln. TA $\rightarrow$ DPR & 0,022 & 0,618 & 0,537 & Positif/Tidak Signifikan \\
$\mathrm{DER} \rightarrow$ ROE $\rightarrow$ DPR & 0,080 & 0,864 & 0,388 & Positif/Tidak Signifikan \\
\hline
\end{tabular}

Sumber: SmartPLS 3.0 (2021, data diolah) 


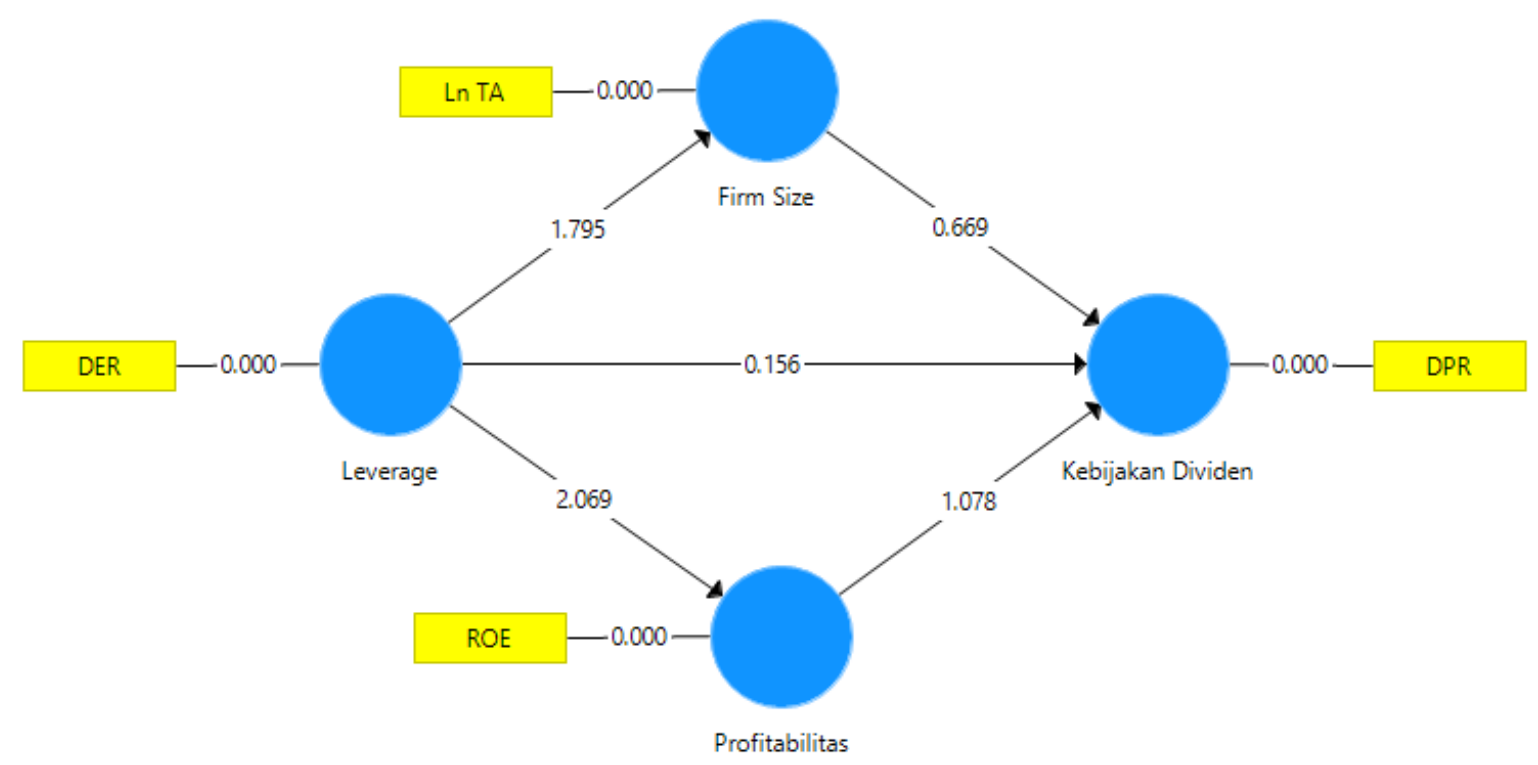

Sumber: SmartPLS 3.0 (2021, data diolah)

\section{Gambar 2. UJI MEASURMENT BOOTSTRAPING MODEL}

\section{Pengaruh Leverage terhadap Firm size}

Hasil pengolahan data menunjukkan leverage tidak memiliki pengaruh terhadap firm size perusahaan sektor agrikultur yang terdaftar di Bursa Efek Indonesia tahun 2014-2018. Hasil riset tersebut merupakan temuan baru yang belum memiliki dasar dari riset terdahulu. Penambahan hutang perusahaan tidak selalu berdampak pada penambahan ukuran perusahaan. Hal ini dapat terjadi karena hutang perusahaan tidak selalu digunakan untuk pembiayaan opersional, sehingga penambahan hutang tidak terlalu berpengaruh terhadap komposisi neraca perusahaan khususnya pada sisi aset perusahaan.

Hasil temuan ini didukung dengan data laporan keuangan perusahaan BISI tahun 2015 nilai DER 0,180 dan nilai $\ln$. TA 14,577. Tahun 2016 nilai DER mengalami peningkatan pada angka 0,171 . Nilai ln. TA mengalami peningkatan menjadi 15,996, sebaliknya, pada perusahaan AALI tahun 2015 nilai DER 0,839 dan nilai ln. TA 16,884. Tahun 2016 nilai DER mengalami penurunan cukup signifikan menjadi 0,377 . Namun nilai $\ln$. TA justru meningkat pada angka 17,003

Implikasi teori hasil temuan ini tidak sejalan dengan balancing theory yang menjelaskan ketika perusahaan menambah hutang untuk pembiayaan operasional, perusahaan akan mampu meningkatkan kegiatan operasional. Peningkatan ini diharapkan mampu meningkatkan ukuran perusahaan (Kautsar, 2014). Implementasi praktis hasil temuan ini, diharapkan perusahaan sektor agrikultur yang ingin memperbesar ukuran perusahaan melalui total aset tidak harus menambah hutang perusahaan. Terlebih apabila penambahan hutang tersebut tidak dipergunakan untuk kebutuhan operasional perusahaan.

\section{Pengaruh Leverage terhadap Profitabilitas}

Pengolahan data statistik menunjukkan leverage memiliki pengaruh terhadap profitabilitas perusahaan sektor agrikultur yang terdaftar di Bursa Efek Indonesia tahun 2014-2018. Nilai original sampel dengan nilai positif menjelaskan adanya pengaruh positif. Kenaikan leverage akan berbanding lurus dengan kenaikan profitabilitas. Hasil temuan ini sesuai dengan Kautsar (2019) bahwa leverage memiliki pengaruh positif terhadap profitabilitas.

Hasil tersebut dapat terjadi karena walaupun semakin banyak modal yang dibutuhkan untuk mendanai kegiatan operasional perusahaan, namun perusahaan berupaya meminimalkan kemungkinan melakukan pinjaman. Hal ini, dapat meminimalisir kewajiban untuk pembayaran beban bunga bagi 
Mia Wahyu Nuraini. Pengaruh Leverage terhadap Kebijakan Dividen dengan Firm Size dan Profitabilitas sebagai Variabel Mediasi pada Perusahaan Sektor Agrikultur di BEI Tahun 2014-2018

perusahaan hingga pada akhirnya dapat berpengaruh terhadap jumlah laba perusahaan (Barus \& Leliani, 2013). Hasil ini didukung oleh data laporan keuangan perusahaan SIMP tahun 2014 nilai DER 0,844 dan nilai ROE 0,066. Kemudian di tahun 2015 nilai DER turun menjadi 0,839. Penurunan tersebut diikuti dengan penurunan ROE menjadi 0,021. Tahun 2016 nilai DER kembali mengalami peningkatan pada angka 0,847 , begitu juga dengan nilai ROE yang turut naik pada angka 0,035 .

Implikasi teori hasil temuan ini sesuai dengan balancing theory dan teori dividen residual, yaitu hutang perusahaan akan digunakan secara produktif untuk membiayai investasi dan proses operasional perusahaan (Kautsar, 2014). Jadi, peningkatan hutang akan menghasilkan kapabilitas operasional dan meningkatkan profitabilitas perusahaan (Kautsar, 2014). Implementasi dari hasil temuan ini perusahaan diharapkan dapat menambah hutang perusahaan untuk pembiayaan operasional sehingga dapat meningkatkan produktivitas. Produktivitas ini diharapkan mempu mendongkrak penjualan sehingga pada akhirnya dapat meningkatkan profitabilitas perusahaan.

\section{Pengaruh Leverage terhadap Kebijakan Dividen}

Hasil pengolahan data menunjukkan leverage tidak memiliki pengaruh terhadap kebijakan dividen perusahaan sektor agrikultur yang terdaftar di Bursa Efek Indonesia tahun 2014-2018. Hasil temuan ini selaras dengan Khan et al. (2013) bahwa leverage tidak berpengaruh terhadap naik atau turunnya rasio dividen yang dibayarkan untuk pemegang saham.

Leverage tidak selalu memberikan pengaruh terhadap besaran dividen yang dibagikan pada pemegang saham. Apabila hutang perusahaan meningkat, belum tentu perusahaan akan membayarkan dividen dalam kuantitas yang lebih banyak. Begitu pula sebaliknya, penurunan hutang perusahaan tidak menentukan jumlah dividen yang akan dibayarkan. Hal ini bergantung pada kebijakan perusahaan dalam upaya mempertahankan kepercayaan pemegang saham (Gunawan \& Rusdianti, 2019). Hasil tersebut didukung oleh data laporan keuangan perusahaan AALI tahun 2015 meskipun perusahaan menambah jumlah hutangnya, namun perusahaan tidak membagikan dividen pada tahun tersebut.

Interpretasi teori dari temuan ini tidak selaras dengan balancing theory dan teori dividen residual yang menjelaskan peningkatan hutang perusahaan yang dioptimalkan untuk kegiatan operasional dapat meningkatkan tingkat produksi. Peningkatan produksi akan berdampak pada meningkatnya penjualan sehingga profitabilitas meningkat. Peningkatan inilah yang menyebabkan kemampuan perusahaan untuk membayar dividen semakin tinggi. Implementasi praktis hasil temuan ini, perusahaan tidak harus mengurangi atau meningkatkan hutang dalam upaya mengatur kebijakan dividen. Perusahaan dapat memertimbangkan faktor lain dalam upaya menyusun kebijakan dividen.

\section{Pengaruh Firm size terhadap Kebijakan Dividen}

Hasil pengolahan data menunjukkan firm size tidak memiliki pengaruh terhadap kebijakan dividen perusahaan sektor agrikultur yang terdaftar di Bursa Efek Indonesia tahun 2014-2018. Hasil temuan ini sesuai dengan Harun \& Jeandry (2018) bahwa firm size tidak memiliki pengaruh terhadap naik atau turunnya rasio dividen yang dibayarkan pada pemegang saham.

Besar atau kecilnya besaran dividen yang dibagikan pada pemegang saham tidak dipengaruhi oleh nilai total aset perusahaan. Peningkatan ukuran perusahaan belum tentu meningkatkan kemampuan suatu perusahaan dalam membayar dividen. Begitu pun sebaliknya, penurunan ukuran perusahaan, dalam hal ini adalah total aset, tidak selalu berdampak pada turunnya kemampuan perusahaan dalam membayar dividen (Agustina, 2020). Hal ini terbukti pada perusahaan SIMP tahun 2018 yang memiliki nilai $\ln$. TA besar yaitu 17,361 tidak membuat perusahaan membagikan dividennya pada tahun tersebut sehingga nilai DPR menjadi 0\%. Sebaliknya, meskipun perusahaan BISI memiliki nilai ln.TA yang lebih kecil, namun perusahaan tersebut secara konsisten selalu membayarkan dividen.

Interpretasi teori dari hasil temuan tersebut tidak selaras dengan firm life cycle theory yang mengungkapkan perusahaan lebih besar memiliki kecenderungan membagikan dividen lebih banyak sebab perusahaan yang lebih besar ataupun lebih dewasa serta mempunyai arus kas yang lebih tinggi sehingga kemampuan membayar dividen lebih besar (Mueller, 1972). Implementasi praktis dari 
temuan ini, perusahaan sektor agrikultur disarankan untuk memertimbangkan faktor lain di luar firm size dalam menentukan kebijakan dividen atau menentukan besaran jumlah dividen yang akan dibayar pada pemagang saham.

\section{Pengaruh Profitabilitas terhadap Kebijakan Dividen}

Hasil pengolahan data menunjukkan profitabilitas tidak memiliki pengaruh terhadap kebijakan dividen perusahaan sektor agrikultur yang terdaftar di Bursa Efek Indonesia tahun 2014-2018. Hasil temuan ini sesuai dengan Mutia (2019) bahwa profitabilitas tidak memiliki berpengaruh terhadap naik atau turunnya rasio dividen yang dibayarkan pada pemegang saham.

Profitabilitas yang tinggi bukan menjadi tolok ukur kapabilitas perusahaan dalam membayarkan dividen. Perusahaan yang memiliki profitabilitas tinggi belum pasti membayarkan dividen dengan jumlah yang besar pula. Profitabilitas rendah juga tidak menunjukkan kapabilitas perusahaan dalam membagikan dividen rendah (Agustina, 2020). Meskipun tahun 2015 perusahaan ANJT mengalami kerugian dengan nilai ROE -0,022, perusahaan tetap membayarkan dividen. Hal ini berbanding terbalik dengan perusahaan SSMS tahun 2018 yang memeroleh laba dengan nilai ROE 0,030 perusahaan tersebut tidak melakukan pembayaran dividen.

Interpretasi teori dari hasil penelitian ini tidak selaras dengan teori dividen residual yang mengungkapkan semakin besar laba yang dihasilkan perusahaan maka berbanding lurus dengan dividen yang dibayarkan (Titman et al., 2014). Perusahaan dengan laba tinggi diharapkan memiliki lebih banyak sisa laba setelah digunakan sebagai pembiayaan investasi untuk dibagikan kepada pemegang saham. Implementasi praktis dari riset ini, perusahaan sektor agrikultur tidak harus memerhatikan profitabilitas dalam merumuskan kebijakan dividen. Sebaiknya, perusahaan dapat memerhatikan faktor lain selain profitabilitas.

\section{Pengaruh Leverage terhadap Kebijakan Dividen melalui Firm size}

Hasil pengolahan data menunjukkan firm size tidak mampu memediasi hubungan leverage terhadap kebijakan dividen perusahaan sektor agrikultur yang terdaftar di Bursa Efek Indonesia tahun 20142018. Besar atau kecilnya ukuran perusahaan tidak memengaruhi hubungan leverage pada kebijakan dividen. Hasil ini dapat terjadi sebab besar kecilnya total aset tidak menjamin kemudahan perusahaan dalam memeroleh akses pada pasar modal dan akan meningkatkan kemampuan perusahaan dalam membagikan dividen (Agustina, 2020). Begitu pula dengan besaran jumlah dividen yang dibagikan tidak dipengaruhi oleh besaran hutang perusahaan. Perusahaan tetap berupaya untuk membagikan dividen tanpa memerhatikan leverage dan ukuran perusahaan agar kepercayaan investor dapat dipertahankan.

Interpretasi teori dari hasil temuan ini tidak sesuai dengan balancing theory dan firm life cycle theory yang menjelaskan bahwa peningkatan hutang yang digunakan untuk pembiayaan operasional akan berpengaruh pada peningkatan ukuran perusahaan. Dengan meningkatnya ukuran perusahaan diharapkan mampu meningkatkan kapabilitas perusahaan dalam membagikan dividen kepada investor atau pemegang saham. Implementasi praktis dari penelitian ini, perusahaan tidak harus memertimbangkan faktor leverage maupun firm size dalam menyusun kebijakan dividen. Perusahaan dapat memertimbangkan faktor lain di luar leverage dan firm size. Hasil riset ini merupakan temuan baru yang belum memiliki dasar dari riset terdahulu.

\section{Pengaruh Leverage terhadap Kebijakan Dividen melalui Profitabilitas}

Hasil pengolahan data menunjukkan profitabilitas tidak mampu memediasi hubungan leverage terhadap kebijakan dividen perusahaan sektor agrikultur yang terdaftar di Bursa Efek Indonesia tahun 2014-2018. Temuan ini didukung oleh Kautsar (2014) yang menunjukkan profitabilitas tidak mampu memediasi hubungan leverage terhadap kebijakan dividen. Pada penelitian sebelumnya, leverage mampu memengaruhi profitabilitas secara langsung dengan lebih baik, namun leverage tidak mampu memengaruhi hubungan terhadap kebijakan dividen secara langsung. Hal ini dikarenakan hutang perusahaan tidak selalu dipergunakan untuk pembiayaan operasional. Profitabilitas perusahaan juga 
Mia Wahyu Nuraini. Pengaruh Leverage terhadap Kebijakan Dividen dengan Firm Size dan Profitabilitas sebagai Variabel Mediasi pada Perusahaan Sektor Agrikultur di BEI Tahun 2014-2018

tidak memengaruhi perusahaan dalam menentukan kebijakan dividen, sehingga apabila perusahaan mengalami peningkatan laba ataupun mengalami kerugian perusahaan dapat tetap membagikan dividen kepada pemegang saham guna menjaga kepercayaan dan eksistensi perusahaan di kalangan investor (Agustina, 2020).

Interpretasi teori dari riset ini tidak selaras dengan balancing theory dan teori dividen residual yang menjelaskan peningkatan hutang yang dipergunakan untuk pembiayaan operasional akan meningkatkan tingkat produksi yang kemudian diharapkan mampu mendongkrak penjualan. Peningkatan penjualan diharapkan dapat menghasilkan keuntungan yang lebih sehingga akan lebih banyak laba yang dapat digunakan untuk membayar dividen. Manfaat praktis dari riset ini, perusahaan dapat memertimbangkan faktor di luar leverage dan kebijakan dividen dalam merumuskan kebijakan dividen atau besaran jumlah dividen yang dapat dibagikan pada shareholder. Hasil riset ini didukung oleh Kautsar (2014) yang mengungkapkan profitabilitas yang diproksikan dengan ROE tidak mampu memediasi hubungan leverage terhadap kebijakan dividen.

\section{KESIMPULAN}

Leverage terbukti memengaruhi profitabilitas. Hasil dari riset tersebut menandakan arah positif. Leverage tidak terbukti memengaruhi firm size dan kebijakan dividen. Firm size tidak memengaruhi kebijakan dividen. Profitabilitas tidak memberikan pengaruh pada kebijakan dividen. Firm size dan profitabilitas tidak terbukti mampu memediasi hubungan leverage terhadap kebijakan dividen, karena secara parsial variabel $\mathrm{x}$ juga tidak terpengaruh secara signifikan dan didukung dengan tidak signifikannya variabel mediator secara parsial terhadap variabel dependen penelitian ini.

Implementasi praktis bagi perusahaan, khususnya sektor agrikultur yang menjadi objek penelitian, perlu memerhatikan faktor leverage yang berpengaruh positif terhadap profitabilitas. Tingkat profitabilitas perusahaan dipengaruhi oleh leverage. Hutang yang dimanfaatkan untuk pembiayaan operasional akan meningkatkan produksi perusahaan. Peningkatan produksi akan mendongkrak penjualan sehingga dapat meningkatkan potensi laba perusahaan. Perusahaan sebaiknya perlu memerhatikan faktor lain selain variabel yang yang dipaparkan di atas dalam upaya meningkatkan ukuran perusahaan, profitabilitas, dan menentukan kebijakan dividen yang sesuai dengan kebutuhan perusahaan.

Bagi investor yang ingin berinvestasi, khususnya pada perusahaan sektor agrikultur, yang menjadi objek penelitian, disarankan untuk memerhatikan faktor leverage atau hutang perusahaan. Meskipun dalam penelitian ini leverage tidak berpengaruh secara signifikan, namun leverage memiliki hubungan negatif terhadap kebijakan dividen. Peningkatan hutang perusahaan berpotensi menurunkan kemampuan perusahaan dalam membayarkan dividen. Saran untuk penelitian selanjutnya diharapkan untuk menambah sampel data yang akan digunakan agar memberikan hasil riset yang lebih optimal. Selain itu perlu dipertimbangkan faktor di luar penelitian ini seperti sales growth (Kautsar, 2014) dan rasio likuiditas (Meiliani \& Amboningtyas, 2017).

\section{DAFTAR PUSTAKA}

Agustina, N. (2020). Pengaruh Cash Position dan Firm Size terhadap Kebijakan Dividen dengan Profitabilitas sebagai Variabel Mediasi pada Perusahaan Sektor Agrikultur. Jurnal Ilmu Manajemen (JIM), 8(2), 586-598. https://jurnalmahasiswa.unesa.ac.id/index.php/jim/article/view/33564

Badan Pusat Statistik. (2018). Produk Domestik Bruto Indonesia Triwulanan 2014-2018. diunduh dari https://www.bps.go.id/publication/2018/10/05/02d80724b71eb684620a2e88/pdb-indonesiatriwulanan-2014-2018.html tanggal 3 Januari 2021

Banerjee, S. (2016). Determinants of Dividend Policy for Select Information Technology Companies in India:An Empirical Analysis. Parikalpana: KIIT Journal of Management, 12(2), 152. 
https://doi.org/10.23862/kiit-parikalpana/2016/v12/i2/132993

Barus, A., \& Leliani. (2013). Analisis Faktor-Faktor yang Mempengaruhi Profitabilitas pada Perusahaan Manufaktur yang Terdaftar di Bursa Efek Indonesia. JWEM (Jurnal Wira Ekonomi Mikroskil), 3(2), 111-121.

Budiarso, N. S. (2018). The Signals of Dividend. Jurnal Accountability, 7(01), 42-47. https://doi.org/10.32400/ja.24806.7.01.2018.42-47

Fahmi, I. (2014). Manajemen Keuangan Perusahaan dan Pasar Modal. Jakarta: Mitra Wacana Media.

Fitri, R. R., Hosen, M. N., \& Muhari, S. (2016). Analysis of Factors that Impact Dividend Payout Ratio on Listed Companies at Jakarta Islamic Index. International Journal of Academic Research in Accounting, Finance and Management Sciences, 6(2), 87-97. https://doi.org/10.6007/ijarafms/v6-i2/2074

Gunawan, T., \& Rusdianti, E. (2019). Pengaruh Debt to Equity Ratio, Profitability dan Firm Size terhadap Effetive Tax Rate serta Dampaknya terhadap Dividend Payout Ratio. Jurnal Riset Ekonomi dan Bisnis, 12(1), 37-54.

Hanif, M., \& Bustaman. (2017). Pengaruh Debt to Equity Ratio, Return on Asset, Firm Size, dan Earning Per Share terhadap Dividend Payout Ratio (Studi pada Perusahaan Manufaktur yang Terdaftar di Bursa Efek Indonesia Tahun 2011-2015). Jurnal Ilmiah Mahasiswa Ekonomi Akuntansi, 2(1), 73-81.

Harun, S., \& Jeandry, G. (2018). Pengaruh Profitabilitas, Free Cash Flow, Leverage, Likuiditas dan Size terhadap Dividen Payout Ratio (DPR) pada Perusahaan Manufaktur yang Terdaftar di Bursa Efek Indonesia. Jurnal Riset Akuntansi, 5(2), 122-137.

idx.co.id. (2021). Laporan Keuangan Perusahaan Tercatat. www.idx.co.id diunduh tanggal 28 September 2020

Kasmir. (2017). Analisis Laporan Keuangan. Jakarta: Rajawali Pers.

Kautsar, A. (2014). Analisis Pengaruh Firm Size, DER, dan Sales Growth terhadap Dividend Payout Ratio Dengan ROE sebagai Variabel Intervening pada Perusahaan Non Keuangan yang Listed di BEI Tahun 2009-2011. Jurnal Bisnis Strategi, 23(2), 1-13. https://doi.org/10.14710/jbs.23.2.1-13

Kautsar, A. (2019). Profitability is a Mediation Variable of Debt on Dividend Payout Indonesian Agriculture Companies. Scholars Journal of Economics, Business and Management, 6(2), 143146. https://doi.org/10.21276/sjebm.2019.6.2.9

Kementrian Pertanian Republik Indonesia. (2019). Pertumbuhan PDB Pertanian RI 2018 Melebihi Target. www.pertanian.go.id. https://www.pertanian.go.id/home/?show=news\&act=view\&id=3726 diunduh tanggal 6 Maret 2021

Khan, F. A., \& Ahmad, N. (2017). Determinants of Dividend Payout: An Empirical Study of Pharmaceutical Companies of Pakistan Stock Exchange (PSX). Journal of Financial Studies \& Research, 2017, 1-16. https://doi.org/10.5171/2017.538821

Khan, W., Naz, A., Khan, W., Khan, Q., Khan, T., \& Mughal, I. (2013). Impact Assessment of Financial Performance and Leverage on Dividend Policy of Pakistan Chemical and 
Mia Wahyu Nuraini. Pengaruh Leverage terhadap Kebijakan Dividen dengan Firm Size dan Profitabilitas sebagai Variabel Mediasi pada Perusahaan Sektor Agrikultur di BEI Tahun 2014-2018

Pharmaceutical Industries. Middle East Journal of Scientific Research, 16(10), 1376-1382. https://doi.org/10.5829/idosi.mejsr.2013.16.10.11862

DOI:

10.5829/idosi.mejsr.2013.16.10.11862

Kusumo, C. Y., \& Darmawan, A. (2016). Pengaruh Perputaran Modal Kerja, Ukuran Perusahaan, dan Diversifikasi terhadap Profitabilitas (Studi pada Perusahaan Food and Beverage yang Terdaftar di BEI Periode 2013 - 2016). Jurnal Administrasi Bisnis, 57(1), 1-7.

Meiliani, L., \& Amboningtyas, D. (2017). Analisis Pengaruh Rasio Likuiditas, Leverage, dan Profitabilita terhadap Dividend Payout Ratio (DPR) dengan Firm Size sebagai Variabel Intervining pada Perusahaan Manufaktur yang Terdatar di Bursa Efek Indonesia Periode Tahun 2012-2016. Jurnal of Management, 3(3), 1-9.

Mueller, D. C. (1972). A Life Cycle Theory of the Firm. The Journal of Industrial Economics, 20(3), 199-219. https://doi.org/10.2307/2098055

Mui, Y. T., \& Mustapha, M. (2016). Determinants of Dividend Payout Ratio: Evidence from Malaysian Public Listed Firms. Journal of Applied Environmental and Biological Sciences, 6(1), 48-54.

Mutia, V. S. (2019). Pengaruh Net Profit Margin, Return on Asset, Return on Equity, dan Cash Ratio terhadap Kebijakan Dividen (Studi Kasus Pada Perusahaan Manufaktur yang Terdaftar di Bursa Efek Indonesia Periode 2012-2016). Journal of Chemical Information and Modeling, 53(9), 1689-1699.

Nadeem, M., Ahmed, A., \& Ahmad, N. (2015). The Effect of Leverage on Financial Health of the Firms : A Study from Cement Industry of Pakistan. Industrial Engineering Letters. 5(5), 123127.

Nuhu, E. (2014). Revisiting the Determinants of Dividend Payout Ratios in Ghana. International Journal of Business and Social Science, 5(8), 230-238.

Nurhayati, M. (2013). Profitabilitas Likuiditas dan Ukuran PER. Jurnal Keuangan dan Bisnis, 5(2), 144-153.

Nurjanah, L., \& Putri, N. K. (2020). Determinan Kebijakan Dividen. Jurnal Ilmiah Indonesia, 5(7), 314-322.

Ofori, D. E. (2018). Revisiting the Determinants of Dividend Payout Ratios : Evidence from Ghanaian Listed Companies. The International Journal of Business and Management, 6(10), 82-88.

Ogilo, F. (2016). Determinants of Liquidity Risk of Commercial Banks in Kenya. The International Journal of Business and Management, 4(8), 46-51.

Perpatih, Z. S. (2016). Pengaruh "ROA" dan "DER" terhadap Dividend Payout Ratio pada Perusahaan Manufaktur Sektor Industri Dasar dan Kimia yang Terdaftar di Bursa efek Indonesia. e-Jurnal Apresiasi Ekonomi, 4(3), 205-211.

Purba, D. P., Sheren, ., Valent, ., \& Angeline, . (2019). Pengaruh Current Ratio (CR), Debt to Equity Ratio (DER) dan Return on Equity (ROE) terhadap Dividend Payout Ratio (DPR) pada Perusahaan Sektor Industri Barang Konsumsi di Bursa Efek Indonesia (BEI) Tahun 2013 2017. Jurnal Riset Akuntansi Going Concern, 14(1), 214-224. https://doi.org/10.32400/gc.14.1.22647.2019

Rafique, M. (2012). Factors Affecting Dividend Payout : Evidence from Listed Non-Financial Firms 
of Karachi Stock Exchange . Society for Business and Management Dynamics. Business Management Dynamics, 1(11), 76-92.

Sudana. (2011). Manajemen Keuangan Perusahaan Teori dan Praktek. Jakarta: Erlangga.

Sudana, I. M. (2015). Manajemen Keuangan Perusahaan Teori \& Praktik (2 ed.). Jakarta: Erlangga.

Sumail, L. O. (2018). Corporate Governance and Dividend Payout Ratio in Non-Financial Firms Listed in Indonesian Stock Exchange. Business and Economic Horizons, 14(4), 851-861. https://doi.org/10.15208/beh.2018.58

Tahir, M., \& Mushtaq, M. (2016). Determinants of Dividend Payout: Evidence from Listed Oil and Gas Companies of Pakistan. The Journal of Asian Finance, Economics and Business, 3(4), 2537. https://doi.org/10.13106/jafeb.2016.vol3.no4.25

Tandelilin, E. (2010). Portofolio da Investasi (Teori dan Aplikasi). Yogyakarta: Kanisius.

Titman, S., Keown, A. J., \& Martin, J. D. (2014). Financial Management Principles and Applications (Twelfth Ed). Pearson Education Limited. www.pearsoned.co.uk. United States of America.

Wahyuni, S. F., \& Hafiz, M. S. (2018). Pengaruh CR, DER dan ROA terhadap DPR pada Perusahaan Manufaktur di BEI. Jesya (Jurnal Ekonomi \& Ekonomi Syariah), 1(2), 25-42. https://doi.org/10.36778/jesya.v1i2.18

Waswa, C. W., Ndede, F. W. S., \& Jagongo, A. O. (2013). Determinants of Dividend Payout by Agricultural Firms in Kenya [An Empirical Analysis of Firms Listed on the Nairobi Security Exchange]. International Journal of Business and Social Science, 5(11), 63-74. 